\title{
Business Architecture Development of Quality Assurance in Higher Education Institutes using TOGAF
}

\section{H. M. C. Pushpakumara ${ }^{1}$, Prasad M. Jayaweera ${ }^{2}$ \& Wanniarachchige M. K. ${ }^{3}$ \\ ${ }^{1}$ Faculty of Management and Finance, University of Ruhuna, Matara, Sri Lanka \\ ${ }^{2}$ Faculty of Applied Science, University of Sri Jayewardenepura, Nugegoda, Sri Lanka \\ ${ }^{3}$ Faculty of Management and Finance, University of Ruhuna, Matara, Sri Lanka \\ E-mail: chandanap@badm.ruh.ac.lk}

Area/Section: Business Management.

Type of the Paper: Empirical Research.

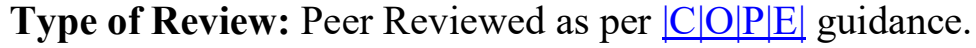

Indexed in: OpenAIRE.

DOI: http://doi.org/10.5281/zenodo.3997472.

Google Scholar Citation: IJMTS.

\section{How to Cite this Paper:}

Pushpakumara, H. M. C., Jayaweera, Prasad M., \& Wanniarachchige, M. K. (2020). Business Architecture Development of Quality Assurance in Higher Education Institutes using TOGAF. International Journal of Management, Technology, and Social Sciences (IJMTS), 5(2), 92-106. DOI: http://doi.org/10.5281/zenodo.3997472.

International Journal of Management, Technology, and Social Sciences (IJMTS) A Refereed International Journal of Srinivas University, India.

(C) With Authors.

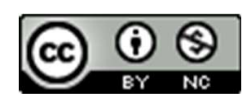

This work is licensed under a Creative Commons Attribution-Non-Commercial 4.0 International License subject to proper citation to the publication source of the work.

Disclaimer: The scholarly papers as reviewed and published by the Srinivas Publications (S.P.), India are the views and opinions of their respective authors and are not the views or opinions of the SP. The SP disclaims of any harm or loss caused due to the published content to any party. 


\title{
Business Architecture Development of Quality Assurance in Higher Education Institutes using TOGAF
}

\author{
H. M. C. Pushpakumara ${ }^{1}$, Prasad M. Jayaweera ${ }^{2}$ \& Wanniarachchige M. K. ${ }^{3}$ \\ ${ }^{1}$ Faculty of Management and Finance, University of Ruhuna, Matara, Sri Lanka \\ ${ }^{2}$ Faculty of Applied Science, University of Sri Jayewardenepura, Nugegoda, Sri Lanka \\ ${ }^{3}$ Faculty of Management and Finance, University of Ruhuna, Matara, Sri Lanka \\ E-mail: chandanap@,badm.ruh.ac.lk
}

\begin{abstract}
Recently, quality assurance has attracted widespread attention in higher education institutes in developing countries. Such initiatives mainly focus on standardising higher education while improving the relevance of degree programs. Nevertheless, current quality assurance mechanisms, particularly in developing countries, heavily rely on a document based manual review process. Given the drawbacks associated with such processes, the necessity of technology-based solutions is being recognised. Even though information system applications are widely used nowadays by the universities to increase the efficiency, quality improvement aspects have not been given due focus. TOGAF is a widely accepted cyclic approach for developing enterprise architecture. This study demonstrates how a TOGAF based business architecture can be used to analyse and improve the existing teaching-learning process in higher education as an integral part of quality assurance.
\end{abstract}

Keywords: Quality assurance, higher education, business architecture, TOGAF.

\section{INTRODUCTION :}

Quality assurance in service-oriented industries mainly focuses on the service delivery process while maintaining the accountability. As a growing service sector, higher education sector has a high focus on improving the quality of their services [1]. In higher education, quality assurance aims to improve the quality of teaching and learning process while standardising the study programs and institutes based on predetermined academic and professional standards. However, there is no universally accepted ways on how to manage the quality in higher education institutes [2].

Generally, quality assurance system includes internal and external quality assurance mechanisms $[3,4]$. The internal quality assurance mainly focuses on maintaining and improving the department, faculty and institution all level quality aspects, achieving the objectives of internal quality assurance system. Moreover, external quality assurance process primarily focuses on standardisation and compliance at the national or international level quality assurance systems [4]. Both internal and external quality assurance are evaluated based on verbal, written and visual evidences by different internal and external evaluations i.e., institutional review, programme review, subject review and library review. A typical review process goes through the self-evaluations, internal reviews and external reviews to ensure the authenticity of the quality assurance. In many countries, both internal and external quality assurance review processes are still largely based on historical documentary evidences which are fairly detached from the on-going service delivery process [5, 6]. One of the reasons for this situation is limited use of technology [7, 8]. Further, the current cyclic quality assurance review process is fairly complex and involves a range of redundant and non-value adding activities due to which the higher education institutes face a number of practical issues during the implementation. Therefore, the existing manual quality assurance framework and process needs to be improved while integrating suitable technologies.

H. M. C. Pushpakumara, et al, (2020); www.srinivaspublication.com 
In fact, universities and other higher education institutes have deployed variety of information systems by automating regular academic and administrative activities. Here, some of the systems have focused on selected quality assurance related processes such as evaluation $[9,10]$ courses and programme specifications [11], teaching and learning [11, 12], and external quality assurance [13]. Although those systems have significantly contributed to assure the quality, they have been addressed only selected quality aspects in the higher education domain. Therefore, those system developments need to be further improved as a complete quality assurance information system solution by integrating existing information system modules.

Student information systems, learning management systems (LMS), human resources (HR), finance, library services, content management systems (CMS)can be considered as major modules of the higher education information systems [14]. In many universities these modules function as isolated or partially integrated systems [15]. Even though, all of these modules are required in a collaborative quality assurance environment, due to differences in scopes, standards and technological basis, their integration has become a challenge.

This challenge can be partially mitigated through the development of a sound architecture framework. Architecture framework guides the development of a fairly automated and integrated quality assurance systems. This study mainly focuses on designing an architecture framework for information system based automated quality assurance solution for higher education institutes particularly considering the Sri Lankan context. In doing so, this study focuses only on the teaching and learning process due to the scope and complexity of the entire quality assurance system. However, the approach presented in this study can be applied in other processes as well.

\section{RELATED WORKS :}

Quality assurance agencies and accreditation bodies take the lead in formulating standards and evaluation criteria, evaluation and accreditation of higher education institutes, promoting good practices, and engaging in other quality improvement activities of higher education institutes [13, 16-19]. The Quality Assurance Agency for Higher Education (QAA), European Quality Assurance Agency (EQAA), Council for Higher Education Accreditation (CHEA), and European Association for quality assurance in Higher Education (ENQA) are such internationally recognised quality assurance and accreditation agencies in UK, US and Europe. Those regional and national level quality assurance and accreditation bodies are networked together under different quality assurance networks such as International Network for Quality Assurance Agencies in Higher Education (INQAAHE) and Asia Pacific Quality Network (APQN). Quality Assurance and Accreditation Council (QAAC), Sri Lanka is the first quality assurance agency in the Asia Pacific region with both of APQN and INQAAHE memberships [18]. These quality assurance authorities have formulated and recommended necessary evaluation mechanisms to assure and improve the quality assurance through cyclic reviews.

As argued earlier, existing cyclic review processes like institutional reviews and programme reviews heavily rely on documentary evidences and physical observations [13]. This makes the quality assurance a timeconsuming task not only for the reviewers but also for the higher education institute being evaluated. Further, this process heavily depends on subjective judgments of the reviewers, frequently, leading to inconsistencies in evaluation outcomes.

At present higher education institutes use their own computerised information systems to automate different types of academic and administrative activities[20]. Students information systems (SIS), student evaluation systems (SES), learning management systems (LMS), academic accountability and workload model (AAWM)and library management system (LibMS) are common examples for such systems. Unarguably, these systems increase the efficiency of delivering study programmes and related administrative activities. Yet these systems do not have a systematic focus on quality assurance aspects [21].

Although, these quality assurance matters can be addressed at the initial stage of a new system development, existing systems have to be treated differently. One option is to establish a separate management system to integrate the existing information systems. Even if a quality assurance management process can function 


\section{International Journal of Management, Technology, and Social Sciences (IJMTS), ISSN: 2581-6012, Vol. 5, No. 2, August 2020.}

separately, quality assurance functions have to be synchronised with other processes running under other information systems. The necessity of separate quality assurance management process has been emphasised by Kettunen and Kantola [22] in the development of management information systems.

Several studies have focused on such framework development using data mining and business process modelling techniques [23], strategic management [21] and balance scorecard [24]. However, several common issues such as retrieving relevant information and working with big data [21] have been observed in the implementation of a quality assurance information systems. Therefore, development of an enterprise architecture with necessary capabilities can be seen as a solution to address these complex planning and designing tasks required for the quality assurance information system.

\section{METHODS :}

As shown in figure 1, the Quality Assurance Ecosystem consists of four main components, namely, Quality Assurance Information System, existing information systems, university data centre and stakeholders. Being the central quality assurance component, attention in this paper is given to the development of a Quality Assurance Information System to address prevailing issues in higher education through providing technology enabled quality assurance services. For this purpose, the study explores the higher education internal processes and stakeholder involvements in relation to quality assurance.

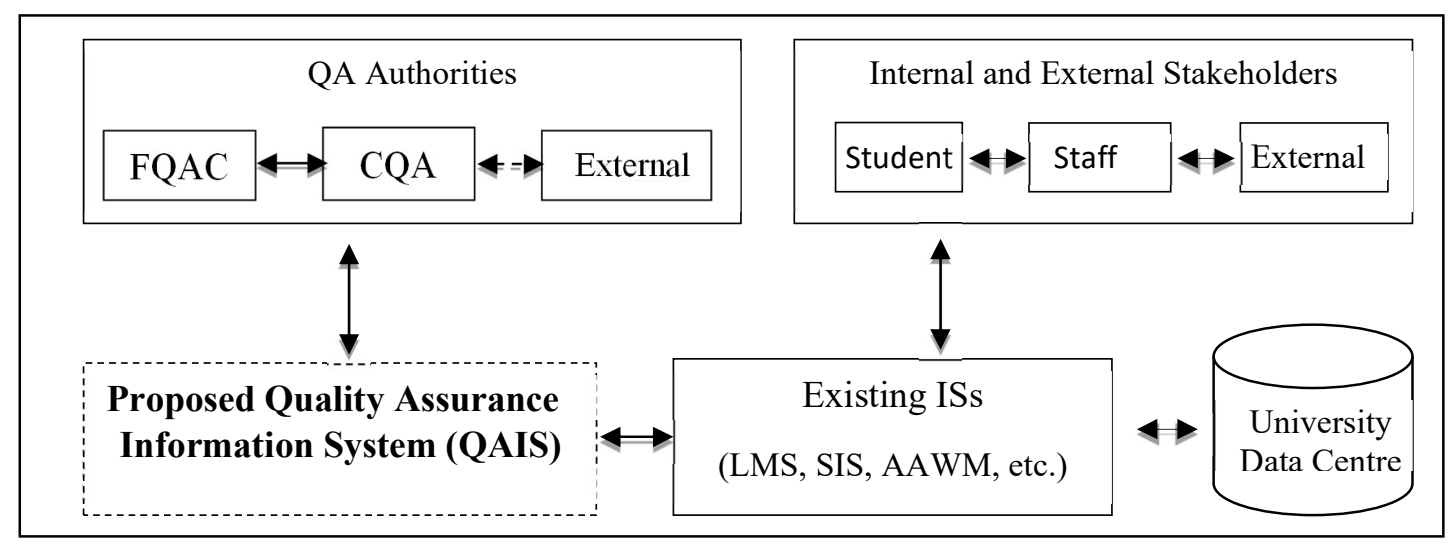

Fig. 1: Quality Assurance Ecosystem

Development of the Quality Assurance Information System goes through the design of architecture of Quality Assurance Information System which includes integrated structural design, its elements and their relationships [25]. This architecture development process of the Quality Assurance Information System is one of the main contributions of this study. Service oriented architecture (SOA) is widely adopted as an enterprise application platform. SOA facilitates business IT alignment and service reusability in a modern dynamic business environment [26] and streamlines the integration of new systems in higher education [27]. Further, SOA entails benefits such as interoperability, modifiability, and reusability [28]. Therefore, the proposed Quality Assurance Information System can be built based on SOA.

As suggested byKabzeva, Niemann, Müller and Steinmetz [26], the complexity of the higher education quality assurance process can be mitigated though adopting an architecture framework during the architecture development process. The Open Group Architecture Framework (TOGAF), Zachman, DoDAF and FEAF are widely accepted enterprise architecture frameworks. Among these, TOGAF is a popular enterprise architecture framework adopted by many organisations [29]. TOGAF has been used in many enterprise architecture development researches relating to the higher education [30-34].

TOGAF Architecture Development Method (ADM) describes an eight phases process of developing and managing an enterprise architecture framework as depicted in figure 2. The phase A, architecture vision, initialise the process by defining the scope, business goals and constraints. The main task of phase B, business 
architecture phase, is to capture the current business architecture, analyse and determine the target business architecture. The phase $\mathrm{C}$, information system architecture, specifies the application and data architectures by identifying necessary applications and data sources required for the automated system. In phase $\mathrm{D}$, the necessary hardware, software and communication technology requirements are determined. Phase E, opportunities and solutions, evaluates the enterprise architecture design completed in phases A to D, and initiate the implementation stage. Thereafter, migration planning, implementation governance and architecture change management are enclosed in phases $\mathrm{F}, \mathrm{G}$ and $\mathrm{H}$.

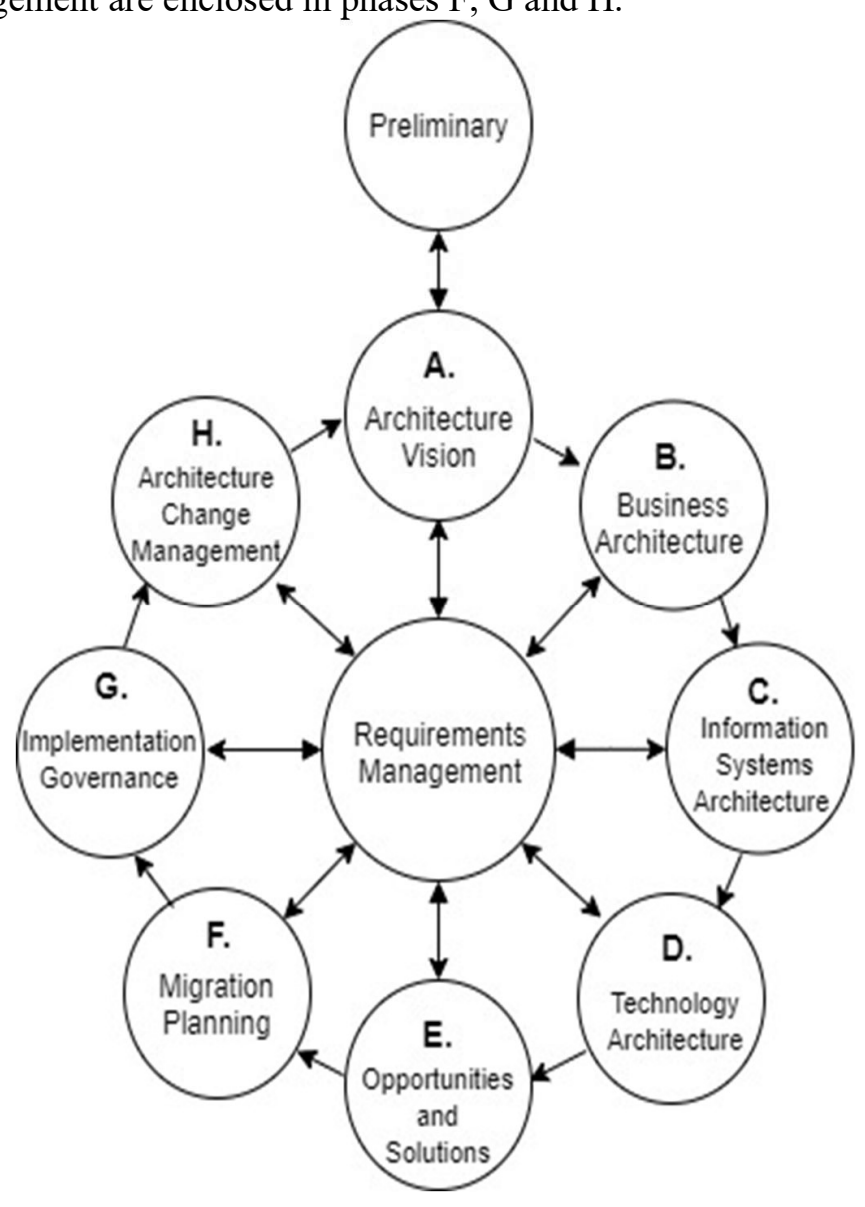

Fig.2: TOGAF architecture development methodology (ADM)

TOGAF ADM phases cover the four principle architecture domains, namely, business, data, applications, and technology [35]. The business architecture describes how the business processes are aligned with the organisation's goals. The data architecture is concerned with how the data is stored, managed and accessed within the organisation. Designing of specific applications and their interactions with other applications are considered in the application architecture. Technology architecture focuses on the necessary hardware and software to support the applications, their interactions and infrastructure for information system deployment. Table 1 lists the respective outputs in each architecture domain.

Table 1: Architecture domain design outputs

\begin{tabular}{ll}
\hline Architecture Domain & Outputs \\
\hline Business architecture & Organisational Structure \\
& Business goals and objectives
\end{tabular}

H. M. C. Pushpakumara, et al, (2020); www.srinivaspublication.com 
International Journal of Management, Technology, and Social Sciences (IJMTS), ISSN: 2581-6012, Vol. 5, No. 2, August 2020.

\begin{tabular}{|l|l|}
\hline & Recognising business processes \\
& Business functions and business services \\
\hline Application architecture & Information systems \\
& Functional services \\
\hline Data architecture & Data analysis \& Reporting \\
& Data restoring and retrieval \\
& Data entities \\
& Data access and integration \\
\hline Technology Architecture & Infrastructure services \\
\hline
\end{tabular}

Among these architecture domains, this study focuses only on the business architecture. Here an attempt is made to analyse the context and develop the business architecture outputs. To this end, the study first identifies the organisational structure and business goals and objectives. This is followed by recognising the business process through decomposing into sub-processes. For illustrating the implementation of TOGAF at the business architecture phase, the teaching and learning process and assessment sub-process were used. Further, Business Process Modelling Notation (BPMN) diagrams were used to represent the process based business architecture outputs. This facilitates an in-depth process analysis with a sophisticated graphical view [36].

\section{RESULTS :}

This study first analyses and designs the organisation structure. Here, the existing organisation structure of the higher education sector and stakeholder engagement in relation to the quality assurance was explored. Second, business process was analysed and Quality Assurance Information System (QAIS) developed. Even though the entire quality assurance process was considered in the initial stage of the analysis, only selected sub-processes and activities were considered in subsequent stages.

\subsection{Organisational structure:}

The origin of the modern university system in Sri Lanka dates back to 1921. The establishment of the University Grants Commission (UGC) in 1978 is a turning point of the higher education in Sri Lanka [37]. As illustrated in figure 3, organisational structure of the state university system in Sri Lanka consist of four levels i.e., University Grants Commission, university, faculties and academic departments.

University Grants Commission acts as the apex body in the state university system, and mainly involves with the planning and coordination of the university education, allocation of funds to higher education institutes, maintenances of academic standards and regulations and students admissions [38]. To undertake the key activities and tasks, business divisions have been established within the University Grants Commission (i.e., planning \& research, quality assurance council, finance). With the support of these business divisions, University Grants Commission works as a corporate body to accomplish the commission's vision, mission, goals and objectives.

According to the Universities Act, the council, senate, and faculty boards act as the main authorities of a state university [39]. The Vice-Chancellor is the university's principal executive officer and principal academic officer. A university consists of several divisions called faculties. Each faculty deals with specific disciplines. Dean is the academic and administrative head of the faculty.

Each faculty consists of several academic departments. Head of the department is the chief academic and administrative officer in the academic department. Academic departments are responsible to offer study programmes in their respective discipline. Academics are assigned to each department and involve in respective study programmes. Moreover, process of new curriculum development and revisions of existing curriculums are also initiated at the academic departments. As such, the academic department plays a critical role in quality assurance process.

Further, figure 3 shows the respective quality assurance authorities in each level. Emphasising the national level governance and commitment to the quality assurance, Quality Assurance Council (QAC) has been 
established under the UGC [13]. QAC was initially established in 2009, as the Quality Assurance and Accreditation Council (QAAC) and later renamed as QAC $[18,40]$. QAC serves the state universities and institutes under the UGC, by reviewing the standards, institutes and study programs [18].

Quality Assurance Council works on implementation of the cyclic external reviews, strengthening the internal quality assurance mechanisms of universities and improvements of their quality of awards [18]. UGC [41] with its commission circular No. 4/2015 issued in 2015, paved the way for establishing internal quality assurance units (IQAU) in each university to facilitate their own internal quality assurance system. While the internal quality assurance unit was chaired by a director, the administrative and financial control was handled by a management committee. The goal of the internal quality assurance units is to promote the quality culture in the university achieving the national level quality assurance goals while ensuring commitment of top-level administration.

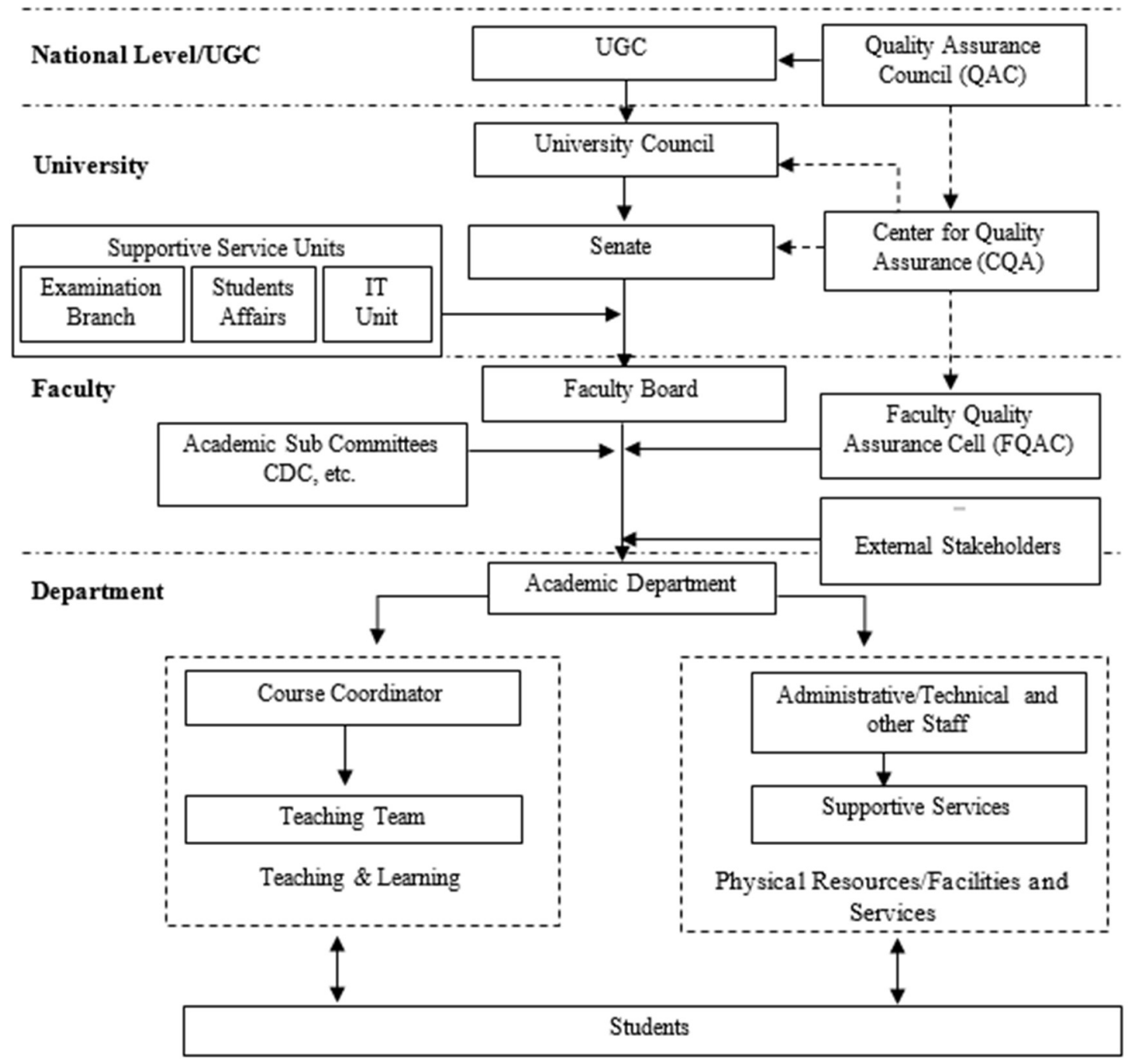

Fig.3: Organisational structure and quality assurance stakeholders in higher education sector

Further improving the provisions made under the aforementioned circular, UGC [42] commission circular No. 9/2019 converted internal quality assurance units into centres for quality assurance (CQA). This further empowered the quality assurance mechanism. For instance, the management committee of the internal quality assurance units was converted into a standing committee of the senate of each university. Instead of the 
director, the standing committee is chaired by the Vice-Chancellor. Further, the director position of the centre for quality assurance has been further strengthened by reducing academic workload and other administration responsibilities of the person holding this post.

Faculty quality assurance cells (FQAC), earlier internal quality assurance cells (IQAC), facilitate the quality assurance mechanism at the faculty level with the consultation of the centres for quality assurance. An academic from each academic department represents the faculty quality assurance cells by linking the quality assurance mechanism with academic departments. This systematic hierarchy of the quality assurance spreading from University Grants Commission to the department level is highly effective in implementing and improving of the quality assurance within the system.

Further, stakeholder accountability to the quality assurance process and their satisfaction is also critical to the success of the quality assurance [43, 44]. Although, the internal stakeholders (i.e. students, lecturers and other support staff) are actively engaged with quality assurance, external stakeholders involvement is minimum [45]. Nevertheless, external stakeholders' participation in the quality assurance activities i.e., programme or course design and development and external review, has been considered and evaluated in institutional and programme reviews too [5, 6]. Therefore, the quality assurance systems need proper mechanism to engage external stakeholders, where necessary, while streamlining the internal stakeholder participation.

\subsection{Business process analysis:}

Achieving excellence in higher education committed to the academic, research and community services is implicated by the typical vision and mission of a higher education institutes. The goals, objectives and strategies of higher education institutes in Sri Lanka, indicate a high concern on improvements in quality of education, research and innovation, staff development, teaching and learning, administration, physical resources, information system applications, financial management and social responsibilities. Therefore, these areas can be considered as critical areas in the higher education context which need continuous improvements [46-49]. Quality assurance can ensure the functionalities of these key areas in achieving the expected goals and objectives.

Local and international higher education quality assurance frameworks reveal that quality assurance has mainly focused on specific policies and procedures such as, 1. Governance and management, 2. Managing quality assurance and improvement, 3. Teaching and learning process, 4. Student administration and support services, 5. Managing learning resources, 6. Managing facilities and equipment, 7. Financial planning and management, 8. Employment process management, 9. Managing research and innovation, and 10. Community services $[19,50,51]$. Each of these internal quality assurance aspects represent one or more complex processes. Therefore, these processes monitors, controls, and improves the quality assurance process can be further simplified by analysing them into sub-processes. As an illustration, the teaching and learning process is analysed into its sub-processes as depicted in table 2.

Among identified 10 internal quality aspects, quality assurance frameworks are primarily focused on assuring quality of teaching and learning process $[40,51,52]$. Curriculum, its reviews and improvements, evaluation of teaching and learning by peers and students, formative feedback by student, staff developments, standardise the assessments are key quality assurance measures of the teaching and learning process [53-55]. Together with quality assurance framework, institution or programme specific approaches have been adopted to enhance the quality of teaching and learning process by higher education institutes, i.e., innovative teaching and learning activities, technology-enabled teaching and learning.

In view of these facts, seven sub-processes can be identified in relation to teaching and learning as illustrated in table 2. Each of these processes is connected with specific quality standards and Key Performance Indicators (KPIs). Achievement of each KPI shall be reflected in one or more specific quality assurance evidences. Therefore, KPIs can be used as indicators for specific process or sub-process, to evaluate the achieved level of respective quality standard. In addition to the listed KPIs in the table, additional KPIs and matrixes can be defined to track the business processes in the specific context. 
Nevertheless, the seven sub-processes illustrated in table 2, need to be further analysed to facilitate the subsequent system development activities. This is because, the automation requires the process to be as simplified as possible. Identified sub-processes can be simplified by identifying respective atomic level activities. For illustration, the assessment sub-process was selected in this study since this is one of the subprocess suitable for increased automation.

Assessment can be either formative or summative. The formative assessment is used as a teaching as well as assessment tool which can be used as a guide for future works by improving the teaching, course contents, structure, and supporting facilities based on student feedback [56, 57]. The summative assessment directly evaluates the success rate of students achieving the expected learning outcomes. Among these, summative assessment typically goes through routine and well documented process $[58,59]$.

Table 2: Quality assurance of the teaching and learning process

\begin{tabular}{|c|c|c|}
\hline Sub-process & Quality Standard ${ }^{1}$ & KPI \\
\hline \multirow[t]{2}{*}{$\begin{array}{l}\text { 1. Preparation of } \\
\text { teaching plan }\end{array}$} & $\begin{array}{l}\text { Aligned T \& L strategies, } \\
\text { assessments and } \\
\text { learning outcomes }\end{array}$ & $\begin{array}{l}\text { Curriculum mapping document } \\
\text { Curriculum development Policy }\end{array}$ \\
\hline & $\begin{array}{l}\text { Multiple learning } \\
\text { opportunities }\end{array}$ & $\begin{array}{l}\text { Availability of Internet based activities } \\
\text { Availability of improved learning environment }\end{array}$ \\
\hline \multirow{3}{*}{$\begin{array}{l}\text { 2. Preparation and } \\
\text { provisioning of teaching } \\
\text { materials }\end{array}$} & $\begin{array}{l}\text { Quality of teaching } \\
\text { materials }\end{array}$ & Percentage of positive feedback \\
\hline & $\begin{array}{l}\text { Early provisioning of } \\
\text { teaching materials }\end{array}$ & $\begin{array}{l}\text { Percentage of prompt uploads of course } \\
\text { material }\end{array}$ \\
\hline & $\begin{array}{l}\text { Provide blended learning } \\
\text { environment }\end{array}$ & $\begin{array}{l}\text { No. of planned teaching methods/LMS } \\
\text { activities } \\
\text { Percentage of LMS participation }\end{array}$ \\
\hline \multirow[t]{2}{*}{ 3. Optimal HR allocation } & Qualified academic staff & Percentage of PhD holders \\
\hline & $\begin{array}{l}\text { Continuous staff } \\
\text { development }\end{array}$ & $\begin{array}{l}\text { No. of staff development workshops } \\
\text { Availability of staff induction programme }\end{array}$ \\
\hline $\begin{array}{l}\text { 5. Optimal resource } \\
\text { allocation }\end{array}$ & $\begin{array}{l}\text { Quality of physical } \\
\text { resources }\end{array}$ & $\begin{array}{l}\text { Usage of modern ICT T\&L aids } \\
\text { No. of issues recorded } \\
\text { Percentage of positive feedback }\end{array}$ \\
\hline 6. Enroll students & $\begin{array}{l}\text { Convenience of the } \\
\text { enrolment process }\end{array}$ & $\begin{array}{l}\text { Late submission management process } \\
\text { Percentage of positive feedback }\end{array}$ \\
\hline \multirow[t]{4}{*}{ 7. Deliver the lectures } & $\begin{array}{l}\text { Quality and progress of } \\
\text { teaching }\end{array}$ & $\begin{array}{l}\text { Percentage of positive feedback } \\
\text { Percentage of completed lecture/tutorial hours } \\
\text { Percentage of students participation }\end{array}$ \\
\hline & $\begin{array}{l}\text { Promote the self- } \\
\text { directed and } \\
\text { collaborated learning }\end{array}$ & $\begin{array}{l}\text { Availability of self-directed and collaborative } \\
\text { learning methods }\end{array}$ \\
\hline & $\begin{array}{l}\text { Motivate students for } \\
\text { research, creative works } \\
\text { and discover the new } \\
\text { knowledge }\end{array}$ & $\begin{array}{l}\text { No. of related workshops or seminars } \\
\text { No. of research engaged by students } \\
\text { No. of new products or innovations }\end{array}$ \\
\hline & $\begin{array}{l}\text { Monitor and evaluation } \\
\text { of the T\&L }\end{array}$ & $\begin{array}{l}\text { Availability of monitoring mechanism } \\
\text { No. of monitoring records } \\
\text { No. of peer reviews } \\
\text { Positive feedback of peer reviewers/ students }\end{array}$ \\
\hline
\end{tabular}

H. M. C. Pushpakumara, et al, (2020); www.srinivaspublication.com 
International Journal of Management, Technology, and Social Sciences (IJMTS), ISSN: 2581-6012, Vol. 5, No. 2, August 2020.

\begin{tabular}{|c|c|c|}
\hline & $\begin{array}{l}\text { Manage lectures } \\
\text { workload }\end{array}$ & Average lecture hours per week/semester \\
\hline \multirow[t]{12}{*}{ 7. Assessments } & $\begin{array}{l}\text { Assessment strategy is } \\
\text { aligned with quality } \\
\text { assurance framework }\end{array}$ & $\begin{array}{l}\text { By-law complied with quality assurance } \\
\text { framework }\end{array}$ \\
\hline & $\begin{array}{l}\text { Procedure for designing, } \\
\text { approving, monitoring } \\
\text { and reviewing of } \\
\text { assessment }\end{array}$ & $\begin{array}{l}\text { Availability of records for designing, approving, } \\
\text { monitoring and reviewing of assessment }\end{array}$ \\
\hline & \multirow{2}{*}{$\begin{array}{l}\text { Review and amendments } \\
\text { of assessment strategies }\end{array}$} & Assessment related By-law amendments \\
\hline & & Summary report of the stakeholder feedback \\
\hline & \multirow{2}{*}{$\begin{array}{l}\text { Adopts the policies and } \\
\text { regulations of } \\
\text { conducting assessments }\end{array}$} & $\begin{array}{l}\text { Summary report of appointments and approval } \\
\text { of course coordinators and evaluators }\end{array}$ \\
\hline & & Internal and External examiner reports \\
\hline & \multirow{3}{*}{$\begin{array}{l}\text { Efficient examination } \\
\text { management }\end{array}$} & Availability of exam management mechanism \\
\hline & & Positive feedback of the stakeholder \\
\hline & & Provide information and services timely \\
\hline & \multirow{2}{*}{$\begin{array}{l}\text { Provides convenient } \\
\text { environment for } \\
\text { assessments }\end{array}$} & Availability necessary physical resources \\
\hline & & Facilities for differently abled students \\
\hline & $\begin{array}{l}\text { Results are released on } \\
\text { promised date }\end{array}$ & No. of delayed days to release the results \\
\hline
\end{tabular}

The summative assessment sub-process involves sequence of activities to be carried out according to specific regulations. Here, the examination division coordinates the entire process in consultation with the academic authorities. Academics, heads of each departments, faculty boards, senate, examination division and students are the key stakeholders in the summative assessment process.

The examination process can be further streamlined and developed as a model, through analysing the constituent atomic activities, corresponding stakeholders and their roles. This reduces the risks associated with subsequent system developments. Business Process Modelling Notation (BPMN) diagrams showing the sequence of activities and the information flow among stakeholders can be used to visualise this model. As an illustration, the BPMN diagram depicted in figure 4 shows the summative assessments process with its atomic activities. Generally, BPMN allows designers to capture and document business processes in a consistent way using a collection of standard symbols to represent different process aspects, i.e., control flows, exchange of documents, resources and their responsibilities. This reduces the communication gap between business process design and implementation. BPMN diagrams have become a common language which visualises business process and illustrates how its activities function. These standard notations were developed by Object Management Group (OMG). 


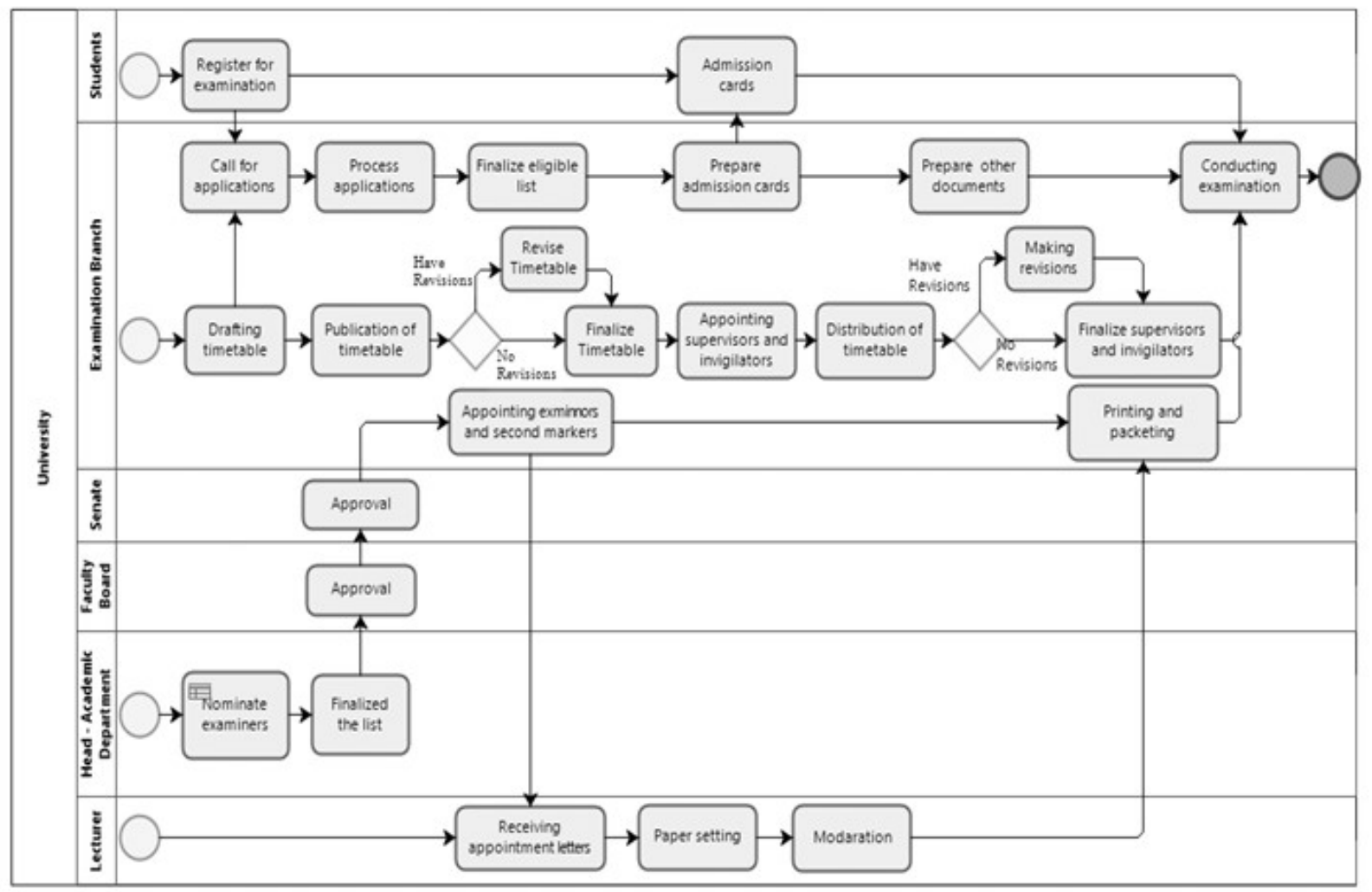

4.3 QAIS development:

Fig. 4: BPMN Diagram for students' summative assessment

Being the central component in the quality assurance ecosystem, the QAIS provides the necessary services to monitor, control and improve the quality assurance process while promptly making reliable quality assurance information available to the stakeholders. As shown in figure 5, the proposed QAIS consists of four modules, i.e., quality assurance manager (QA Manager), quality assurance repository, quality assurance rule-base and dashboard. The quality assurance manager closely interacts with quality assurance frameworks and institutional policies and procedures complying necessary quality assurance tasks. Further, QAIS provides user-friendly and ubiquitous interface for the stakeholders based on specified access privileges to carryout respective quality assurance tasks.

As mentioned in section 3, the QAIS enhances the interoperability among the, existing information system modules. Here, QAIS needs an efficient mechanism for communicating with other information systems. For example, service of a massaging broker can be employed to communicate with existing legacy system [60]. Further, massaging standards can be defined to communicate with new information system modules, if introduced later.

QA Manger monitors, controls, and improves the quality assurance process in a proactive manner i.e., alerts and involves with the running processes to validate them by triggering the associated quality standard.QA Manager performs four main activities, namely, quality standards management, process management, feedback management and reporting using four submodules. The quality standards management submodule defines and enacts quality standards. The process management sub module defines and improves respective processes. Feedback management sub module involves with feedback related activities. Reporting activities such as recording data and generating regular and on-demand reports are handled by the reporting sub module. 
Further, the QA Manager outputs its information into quality assurance dashboard. This dashboard is designed in such a way that gives meaningful insights on the quality assurance of the higher education institute though an effective representation of KPIs and progress via interactive graphs and tables.

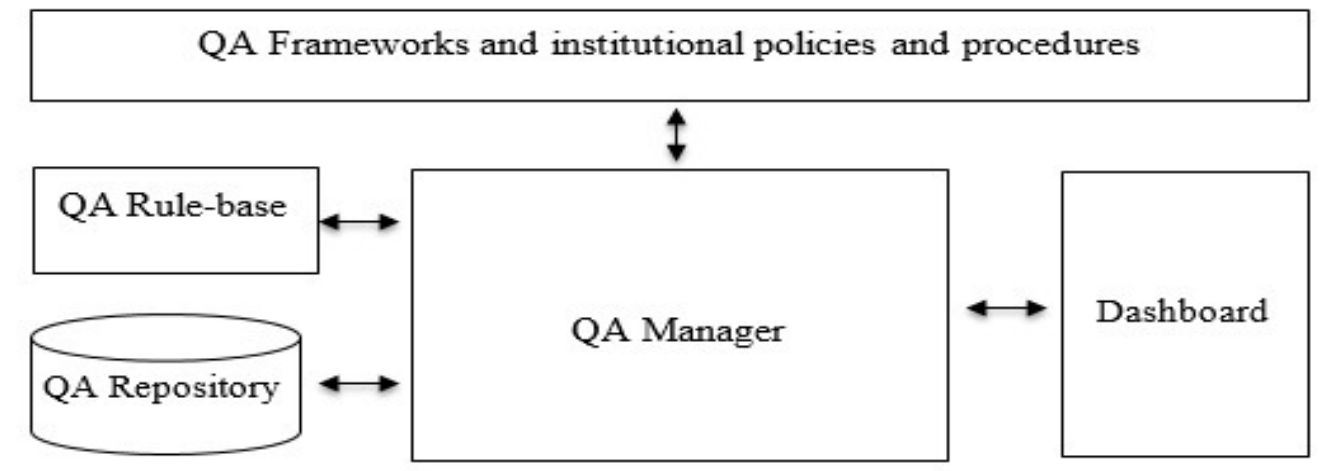

Fig. 5: Main components of the Quality Assurance Information System (QAIS)

\section{DISCUSSION :}

Establishment of a quality assurance ecosystem can address the prevailing issues in higher education quality assurance through providing a sophisticated information system solution integrating QAIS and existing information system modules. TOGAF ADM is an agile solution in developing this type of complex architecture. The business architecture developments enclose the initial process analysis and design, which has not been adequately explored in the in the existing higher education quality assurance literature.

The business architecture development blueprint proposed in this study lays a foundation for quality assurance system developers and quality assurance policy makers through providing a sound analysis framework. The stepwise process analysis technique was highly effective in streamlining and improving the relevant processes while identifying the necessary quality assurance focal points. Initial design of the QAIS focused on possible integration scenarios of both existing legacy and new systems, ensuring the future expansions.

\section{CONCLUSION :}

To develop the business architecture, this study went through architecture vision and business architecture phases of the TOGAF ADM by analysing the selected process and related sub-processes. Nevertheless, the proposed mechanism can be applied to the entire quality assurance system. Moreover, attention needs to be paid to application, data and technology architectures of the QAIS in achieving the ultimate result, a sophisticated real-time QAIS.

\section{REFERENCES :}

[1] Ryan, T. (2015). Quality assurance in higher education: A review of literature. Higher learning research communications, 5,4 .

[2] Becket, N. and Brookes, M. (2006). Evaluating quality management in university departments. Quality Assurance in Education, 14, (2), 123-142.

[3] Stumbrys, E. (2004). Internal and External Quality Assurance in Higher Education. Quality of Higher Education, 1, 158-165.

[4] Paintsil, R. Balancing Internal and External Quality Assurance Dynamics in Higher Education Institutions. 2016.

[5] UGC Manual for Review of Undergraduate Study Programmes of Sri Lankan Universities and Higher Education Institutions City, 2015.

H. M. C. Pushpakumara, et al, (2020); www.srinivaspublication.com 
[6] UGC Manual for Institutional Review of Sri Lankan Universities and Higher Education Institutions City, 2015.

[7] Moussa, N. and Moussa, S. (2009). Quality assurance of e-learning in developing countries. Nonlinear Analysis: Theory, Methods \& Applications, 71(12), e32-e34.

[8] Lim, D. (1999). Quality assurance in higher education in developing countries. Assessment \& Evaluation in Higher Education, 24(4), 379-390.

[9] Kandil, M. S., Hassan, A. E., Asem, A. S. and Ibrahim, M. E.-h. (2010). Prototype of Web2-based system for Quality Assurance Evaluation Process in Higher education Institutions. International Journal of Electrical \& Computer Sciences IJECS-IJENS, 10(02).

[10] Kandel, M., Hassan, A. E., Asem, A. S. and Ibrahim, M. E. (2010). UML analysis for Quality Assurance management System for Higher education. International Journal of Engineering Science and Technology, 2(4), 417-432.

[11] Welsh, J. F. and Dey, S. (2002). Quality measurement and quality assurance in higher education. Quality Assurance in Education2002.

[12] Bourne, R. K., P. (2010). A database approach to feedback-driven teaching quality improvement. Research and Development in Higher Education: Reshaping Higher Education, 33.

[13] Peiris, C. N., Wickramasinghe, S., Peiris, S. E., Meegama, R., Upeksha, G. and Hettiarachchi, S. (2013). Web Based Monitoring and Evaluation System for External Quality Assesment in Universities. INQAAHE Conference, 9-11 April, 2013-Chinese Taipei, City.

[14] Chaushi, B. and Dika, Z. (2013). Higher Education Information Systems: An Overview of the Latest Trends and Issues.

[15] Ribeiro, L. M., Pereira, R. H., Pacheco, O., Bernardes, M. and Martins, R. T. (2016). Interoperability between information systems of Portuguese higher education institutions. City.

[16] Brandenburg, U., Burquel, N., Carr, D., Federkeil, G., Sadlak, J., Urban, J., Wells, P., Westerheijden, D., Nazarko, J. and Kuźmicz, K. (2008). A practical guide. Benchmarking in European Higher Education.

[17] Jung, I., Wong, T. M., Li, C., Baigaltugs, S. and Belawati, T. (2011). Quality assurance in Asian distance education: Diverse approaches and common culture. The International Review of Research in Open and Distributed Learning, 12, (6), 63-83.

[18] Peiris, C. N., Wickramasinghe, S. and Peiris, S. E. Theme: Higher Education Quality Assurance in a Changing World: Envisioning the future of Asia Pacific Anticipating and Responding to Change: Challenges and Success in Quality Assurance of Higher Education - Sri Lankan, 2009.

[19] TEQSA Higher Education Standards Framework. Tertiary Education Quality and Standards Agency, Australia, City, 2014.

[20] Šehidić, A. and Junuz, E. (2016). Quality Assurance in Higher Education Using Business Intelligence Technology. International Journal of Education and Practice, 4(2), 71-83.

[21] Kahveci, T. C., Uygun, Ö., Yurtsever, U. and İlyas, S. (2012). Quality assurance in higher education institutions using strategic information systems. Procedia-Social and behavioral sciences, 55, 161-167.

[22] Kettunen, J. and Kantola, I. (2010). Quality assurance view of a management information system. IGI Global, City, 2010.

[23] Tsolakidis, A., Chalaris, M. and Chalaris, I. (2015). Quality Assurance Information System-The Case of 
the TEI of Athens. International Journal on Integrated Information Management, 2.

[24] Chalaris, M., Tsolakidis, A., Sgouropoulou, C. and Chalaris, I. (2011). Developing an information system for quality assurance in higher education using the balanced scorecard technique-the case study of TEI-A. IEEE, City.

[25] Bernus, P. and Schmidt, G. (1998). Architectures of information systems. Springer, City.

[26] Kabzeva, A., Niemann, M., Müller, P. and Steinmetz, R. (2010). Applying TOGAF to Define and Govern a Service-oriented Architecture in a Large-scale Research Project. City.

[27] Mircea, M. (2012). SOA adoption in higher education: a practical guide to service-oriented virtual learning environment. Procedia-Social and Behavioral Sciences, 31, 218-223.

[28] Selamat, M. H. and Al Kharusi, A. (2009). Service oriented architecture in education sector. International Journal of Computer Science and Network Security, 9, (5), 301-308.

[29] Kotusev, S. (2018). TOGAF-based enterprise architecture practice: an exploratory case study. Communications of the Association for Information Systems, 43(1), 321-359.

[30] Alamri, S., Abdullah, M. and Albar, A. (2018). Enterprise Architecture Adoption for Higher Education Institutions. International Journal of Simulation--Systems, Science \& Technology, 19(5).

[31] Amalia, E. and Supriadi, H. (2017). Development of enterprise architecture in university using TOGAF as framework. AIP Publishing, City.

[32] Holilah, A. S. G. and Saragih, M. H. (2019). Designing IT Blue Print Academic System on Higher Education with Togaf. (2019).

[33] Murpratiwi, S. I., Gustina, A. W. and Dewi, I. C. (2016). Design of Enterprise Information System with TOGAF Framework (Case Study: STD Bali). International Journal of Engineering and Emerging Technology, 1(1).

[34] Nama, G. F. and Kurniawan, D. An enterprise architecture planning for higher education using the open group architecture framework (togaf): Case study University of Lampung. IEEE, City, 2017.

[35] Kurniawan, N. B. Enterprise Architecture design for ensuring strategic business IT alignment (integrating SAMM with TOGAF 9.1). IEEE, City, 2013.

[36] Joni, I. D. M. A. B. and Minartiningtyas, B. A. (2016). Business Process Analysis od Academic System Using Business Process Modeling Notation at StmikStikom Indonesia. Journal of Electrical Engineering and Computer Science, 1(1).

[37] Jayasundara, N. S. (2014). Higher Education Policy in Sri Lanka: Implementation in State Universities. Scientific Research Journal, 41-44.

[38] UGC Establishment of the University Grants Commission, Universities Act - Part I. City, 1978.

[39] UGC The Authorities of a University, Universities Act - Part VII, Uninersity Grants Commission, Sri Lanka. City, 1978.

[40] Ratnasekera, J. L. and Peiris, C. N. Sri Lankan Experience in External Quality Assessments. City, 2006.

[41] UGC Comm. Circular 04/2015 : Strengthening of internal quality assurance systems in universities and Higher Educational Institutions through establishment of internal quality assurance units. City, 2015.

[42] UGC Further Stranthening of IQAUs. City, 2019.

[43] Welzant, H., Schindler, L., Puls-Elvidge, S. and Crawford, L. (2015). Definitions of quality in higher education: A synthesis of the literature. Higher Learning Research Communications, 5(3), 2. 
[44] Leisyte, L. and Westerheijden, D. F. Stakeholders and quality assurance in higher education. Brill Sense, City, 2014.

[45] Imbulgoda, C. Evolution of the Quality Assurance System-A Study of the State Universities in Sri Lanka. 3rd Australia and New Zealand Conference on Advanced Research (ANZCAR-2019 ..., City, 2019.

[46] University of Ruhuna Corporate Plan, University of Ruhuna 2019 - 2023. City, 2019.

[47] University of Kelaniya Corporate Plan University of Kelaniya, 2018-2022. City, 2018.

[48] Sabaragamuwa University of Sri Lanka Strategic Management Plan 2019-2023. City, 2019.

[49] Open University of Sri Lanka Strategic Management Plan 2015-2020, Open University of Sri Lanka. City, 2015.

[50] Loukkola, T. and Zhang, T. Examining quality culture: Part 1-Quality assurance processes in higher education institutions. European University Association Brussels, 2010.

[51] Matei, L. and Iwinska, J. Quality assurance in higher education: A practical handbook. Central European University. Yehuda Elkana Centre for Higher Education, Budapest, Hungary, (2016).

[52] European Association for Quality Assurance in Higher Education Standards and guidelines for quality assurance in the European Higher Education Area (ESG). ENQA Brussels, City, (2015).

[53] Netshifhefhe, L., Nobongoza, V. and Maphosa, C. (2016). Quality Assuring Teaching and Learning Processes in Higher Education: A Critical Appraisal. Journal of Communication, 7(1), 65-78.

[54] Crosling, G., Heagney, M. and Thomas, L. (2009). Improving student retention in higher education: Improving teaching and learning. Australian Universities' Review, The, 51(2), 9.

[55] Steinhardt, I., Schneijderberg, C., Götze, N., Baumann, J. and Krücken, G. (2017). Mapping the quality assurance of teaching and learning in higher education: the emergence of a specialty? Higher Education, 74(2), 221-237.

[56] Sin, C. and Manatos, M. (2014). Student assessment in Portugal: Academic practice and Bologna policy. Higher Education Policy, 27, (3), 323-340.

[57] Box, I. Assessing the assessment: an empirical study of an information systems development subject. Australian Computer Society, Inc., City, 2003.

[58] CQA-University of Ruhuna Manual of Procedures for Conduct of Examinations, University of Ruhuna. City, 2020.

[59] UGC Manual of Procedure for Conduct of University Examinations. City, 1983.

[60] Vasconcelos, A., da Silva, M. M., Fernandes, A. and Tribolet, J. An information system architectural framework for enterprise application integration. IEEE, City, 2004. 